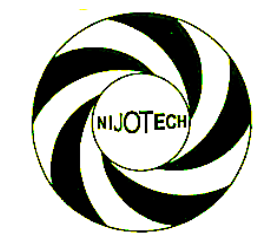

Nigerian Journal of Technology (NIJOTECH)

Vol. 39, No. 2, April 2020, pp. 332 - 337

Copyright@ Faculty of Engineering, University of Nigeria, Nsukka,

Print ISSN: 0331-8443, Electronic ISSN: 2467-8821

www.nijotech.com

http://dx.doi.org/10.4314/njt.v39i2.2

\title{
COMPARISON OF STRENGTH OF SANDCRETE BLOCKS PRODUCE WITH FINE AGGREGATE FROM DIFFERENT SOURCES
}

\author{
Bldr. A. O. Alejo *

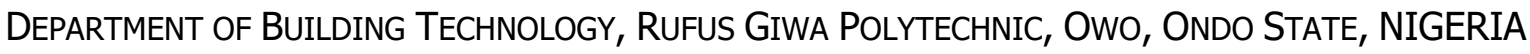 \\ E-mail address: ayourlejo@yahoo.com
}

\begin{abstract}
Sandcrete blocks comprise of water, natural sand cement. Sandcrete blocks are the building units used in the construction of wall and partitions. Diverse sizes of sandcrete blocks are used to construct free standing walls and building structure with load and non - load bearing units. This research work investigate and compared strength of sandcrete blocks produced with fine aggregate from different source in Owo local government area. The targeted areas within Owo local government are Emure, Ipele and Shagari. Sieve analysis was conducted on the samples and the result revealed that all the samples are good for sandcrete block production. Thirty six sandcrete cubes samples were mould. The mix proportion 1:6 was used. Batching by volume was adopted. Curing was done by full immersion of sandcrete and compressive strength test was carried out on each specimen at 7, 14. 21 and 28 days respectively. The percentage of fine aggregate used in this research was $100 \%$ for all samples. The results revealed that sandcrete blocks produced with fine aggregate from Ipele, Shagari and Emure gives compressive strength of 4,15N/MM2, 3.56N/MM² and $5.48 N / M^{2}$ at 28 days respectively. Based on the result of this research work, it is recommended that Emure fine aggregate (sand) is considered as most suitable out of the samples tested for sandcrete blocks production.
\end{abstract}

Keywords: Sand, Sandcrete blocks, Compressive strength, Curing, Production practice.

\section{INTRODUCTION}

British standard (BS 6073) part I [1] defines block as a mansory unit of large size in all dimensions than specified for bricks but no dimensions should exceed $650 \mathrm{~mm}$ nor should the height exceed either its length or six times its thickness. Sandcrete blocks are of various sizes: $225 \mathrm{~mm}$ ( 9 inches), $150 \mathrm{~mm}$ ( 6 inches) , $125 \mathrm{~mm}$ (5 inches ) and $10 \mathrm{~mm}$ (4 inches) respectively.

Over $90 \%$ of physical infrastructures in Nigeria are being constructed using sandcrete blocks, [2]. They are very popular as a long lasting and low maintenance investment for institutional and industrial buildings [3]. Sandcrete blocks are manufactured in many parts of the country (Nigeria) without any reference to suit good quality work or local building requirements [4]. The presence of mineral admixtures in construction materials has been observed to input significant improvement on their workability, strength and durability over the past decade [5]. In an attempt to enhance the manufacturing practice and best materials in the year 2000, the standard organization of Nigeria (SON) developed a reference document which prescribed the minimum requirements and uses of different kinds of sandcrete blocks [6]. In 2004, the document was reviewed thus NIS 87:2004 standard for sandcrete blocks became the country's standard reference document for sandcrete. There was another review thus NIS 87:2007 standard for sandcrete block emerged as the standard reference document for sandcrete block production in Nigeria [7].

The Nigerian industrial standard defines sandcrete block as a composite material made up of cement, sand and water, molded into different sizes [6]. Sandcrete blocks are building units usually made up of ordinary Portland cement, sharp sand obtained from rivers or stream and water from streams, rivers

* Corresponding author, tel: +234 8035962794 
or water boreholes, mixed in appropriate proportions and molded into different desired sizes [8].

Sandcrete blocks can either be solid or hollow rectangular types with $450 \mathrm{~mm} \times 225 \mathrm{~mm} \times 225 \mathrm{~mm}$ and $450 \mathrm{~mm} \times 150 \mathrm{~mm} \times 225 \mathrm{~mm}$ being the most common sizes [9]. Anosike and Oyebade [7] reported that the NIS specified two types of blocks, types $\mathbf{A}$ blocks which are load bearing and type $\mathbf{B}$ blocks which are non - load bearing. Both of them can either be solid or hollow. Sandcrete blocks are relatively cheap when compared to other construction materials. They provide an excellent resistance to damage without the added cost of protection devices. They do not contain any material that is harmful to the environment. Sandcrete blocks do not decay, rust or provide a home for damaging insects as other building materials can [10]. Oyetola and Abdullahi [11] argued that sandcrete has been in use throughout West Africa for over 5 decades as a popular building material for preparation of building blocks and bricks. Right from the inception of production, most concrete mansory units are manufactured on the local level and industry standard are not always adhered to [12-14]. Okoli, et. al [15] argued that apart from manufacturers and entrepreneurs who are producing block strictly for business purposes, quite a number of contractors and clients are also making blocks for use on their projects. Oyekan and Kamiyo [04] added that this comes with great challenge in Nigeria due to the large size of the block manufacturing industry and are inadequately trained.

Chandrasekhar, et.al [16] argued that sancrete is the main building material used for the construction of walls of most post independent building in Nigeria. Samson, et. al [17] agrees that quality and standardization of sandcrete blocks are of paramount importance in the study of building components since these will serve as standards for measurement reflecting the level of development attained by a nation. While quality can be viewed as compliance with specification or 'fitness for purpose'. According to Abdullahi [18] the quality of sandcrete blocks, however is inconsistent due to the different production methods employed and the properties of constituent materials. Quality management and quality assurance on the other hand have been adopted to include all aspect of producing and accepting a construction project which meets all required quality standards [19]. In a similar view Ogunsanmi, et.a I [20] identified quality as one of the three key elements for developing risk classification model for design and build projects. Okafor and Ewa, [21] found that in order to minimize cost and maximize profits, producers of sandcrete blocks in Nigeria reduce the quality of cement needed to give acceptable quality of sandcrete block leading to the flooding of low strength blocks in the commercial markets. Abdullahi [18] studied the compressive strength of sandcrete blocks produced in some parts of minna, Niger state Nigeria and discovered that they were below the minimum NIS standard requirement. Raheem, [22] considered as assessment of the quality of sandcrete blocks produced by LAUTECH block industry, an area of the business ventures of Ladoke Akintola university of Technology, Ogbomoso, Nigeria. The results indicates that compressive strength of $450 \mathrm{~mm} \times 225 \mathrm{~mm} \times 225 \mathrm{~mm}$ (9 inches) blocks increased from $0.54 \mathrm{~N} / \mathrm{MM}^{2}$ at age 3 days to $1068 \mathrm{~N} / \mathrm{MM}^{2}$ at age 28 days. While that of $450 \times 225 \times 150 \mathrm{~mm}$ (6 inches) blocks increased from $0.53 \mathrm{~N} / \mathrm{MM}^{2}$ at age 3 days to $1.59 \mathrm{~N} / \mathrm{mm}^{2}$ at age 28 days. That is, about $60 \%$ of the compressive strength at 28 days was developed at day 7 for both 9 and 6 inches blocks. Boeck, et.a I [23] reported low average compressive strength value of 1.21 $\mathrm{N} / \mathrm{mm}^{2}$ and $0.73 \mathrm{~N} / \mathrm{MM}^{2}$ in dry and wet state respectively. When commercially available sandcrete blocks obtained from block making factories within the federal capital territory, Abuja Nigeria were subjected to test.

Odeyemi, et. al [24] observed that the average compressive strength of manually produced blocks and machine compacted blocks at 28th days of curing were $2.83 \mathrm{~N} / \mathrm{MM}^{2}$ and $2.96 \mathrm{NMM}^{2}$ respectively. Previous research has shown dismal results in the production of sandcrete blocks, which have exhibited compressive strength far below the standard requirement for the construction of houses [25]. Compressive strength is influenced by the level of quality control employed. Afolayan [26] opined that a good selection of materials and adequate curing method among others can influence the compressive strength of sandcrete blocks. Abdullahi opined that [18] blocks should be left to mature for at least 28 days (by curing them) before they are laid if enough if enough strength is needed.

Abdullahi [18] suggests improvement in the selection of materials and curing techniques as remedy for enhancement of the quality of sandcrete blocks. 


\section{MATERIALS AND METHODS}

This study was derived from a survey designed to compare compressive strength of sandcrete block produce with fine aggregate from different sources in Owo local government area. The local government is located in the south west of Nigeria, within the lowland humid tropical rainforest. It is characterized by wet and dry seasons.

Three types of investigations were carried out in this study; namely; field, literature review and interviews. Locally excavated sands ( fine aggregate) used were gotten from three sources in Owo ; at Ofi - Ipele Owo, Shagari Owo and Emure Owo respectively. The cement widely used in Nigeria is the ordinary Portland cement (OPC). Dangote cement with properties conforming to BS (British standard) was used during this research work. There are different sources of water but for the purpose of this study, borehole water was used throughout. The instrument and tools used for the study are solid sandcrete cube mold, sieve machine, head pan, spade and shovel..

Sieve analysis and Techniques of experimental procedure were carried out to achieve the objective of the study targeted at comparing the compressive strength of solid sandcrete blocks produced with fine aggregate (sand) from different sources in Owo local government area.

\section{RESULTS AND DISCUSSIONS}

Tables 1 through 4 show the result of sieve analysis experiment for Ipele, Shagari and Emure sand to determine the different sizes and properties of samples.

Table 1 shows the particle size distribution result for Ipele fine aggregate (sand) with the highest level of percentage finer of $97.6 \%$ with sieve size $3.35 \mathrm{~mm}$ and other percentage were arranged as the sieve sizes decreases. Sieve size $0.452 \mathrm{~mm}$ has the maximum soil retained of $150 \mathrm{~g}$ with percentage retain of $30.2 \%$. Total weight of soil retained $=$ $497 \mathrm{~g}$.

Table 2 shows the grain size distribution result for Shagari fine aggregate (sand) with the highest level of percentage finer of $87.1 \%$ with sieve size $3.35 \mathrm{~mm}$ and other percentage were arranged as the sieve sizes decreases. Sieve size $0.452 \mathrm{~mm}$ has the maximum soil retained of $74 \mathrm{~g}$ with percentage retain of $15.4 \%$. Total weight of soil retained $=482 \mathrm{~g}$.

Table 3 shows the particle size distribution result for Emure fine aggregate (sand) with the highest level of percentage finer of $98.4 \%$ with sieve size $3.35 \mathrm{~mm}$ and other percentage were arranged as the sieve sizes decreases. Sieve size $0.452 \mathrm{~mm}$ and 0.212 has the maximum soil retained of $125 \mathrm{~g}$ with percentage retain of $25.0 \%$. Total weight of soil retained $=501$.

Table 1: Particle size distribution result for Ipele sand sample.

\begin{tabular}{ccccccccc}
\hline $\begin{array}{c}\text { Sieve } \\
\text { size } \\
(\mathrm{mm})\end{array}$ & $\begin{array}{c}\text { Weight of } \\
\text { empty } \\
\text { sieve }(\mathrm{g})\end{array}$ & $\begin{array}{c}\text { Weight of } \\
\text { sieve + soil } \\
\text { retained }(\mathrm{g})\end{array}$ & $\begin{array}{c}\text { Weight of } \\
\text { soil } \\
\text { retained } \\
(\mathrm{g})\end{array}$ & $\begin{array}{c}\text { \% of soil } \\
\text { retained } \\
(\mathrm{g})\end{array}$ & $\begin{array}{c}\text { Weight of } \\
\text { soil } \\
\text { passing } \\
(\mathrm{g})\end{array}$ & $\begin{array}{c}\text { Cum. \% of } \\
\text { soil } \\
\text { retained } \\
(\%)\end{array}$ & $\begin{array}{c}\% \\
\text { passing }\end{array}$ & $\begin{array}{c}\% \\
\text { finer } \\
(\%)\end{array}$ \\
\hline 3.35 & 498 & 510 & 12.0 & 2.4 & 496 & 2.4 & 99.80 & 97.6 \\
2.36 & 487 & 503 & 16.0 & 3.2 & 480 & 5.6 & 96.58 & 94.4 \\
1.70 & 478 & 506 & 28.0 & 5.6 & 452 & 11.2 & 90.95 & 88.8 \\
1.18 & 458 & 509 & 51.0 & 10.3 & 401 & 21.5 & 80.68 & 78.5 \\
0.850 & 437 & 503 & 66.0 & 13.3 & 335 & 34.8 & 67.40 & 65.2 \\
0.425 & 403 & 553 & 150.0 & 30.2 & 185 & 65.0 & 37.22 & 35.0 \\
0.212 & 382 & 498 & 116.0 & 23.3 & 69 & 88.3 & 13.88 & 11.7 \\
0.150 & 365 & 399 & 34.0 & 6.8 & 35 & 95.1 & 7.04 & 4.9 \\
0.075 & 359 & 382 & 23.0 & 4.6 & 12 & 99.7 & 2.41 & 0.3 \\
0.63 & 358 & 359 & 01.0 & 0.2 & 11 & 99.9 & 2.21 & 0.1 \\
Pan & 328 & 328 & 0.00 & 0.00 & 0.00 & 0.00 & 0.00 & 0.00 \\
\hline
\end{tabular}

Source: Author laboratory work, 2019. 
Table 2: Particle size distribution result for Shagari sand sample.

\begin{tabular}{lllllllll}
\hline $\begin{array}{l}\text { Sieve } \\
\text { size } \\
(\mathrm{mm})\end{array}$ & $\begin{array}{l}\text { Weight of } \\
\text { empty } \\
\text { sieve }(\mathrm{g})\end{array}$ & $\begin{array}{l}\text { Weight of } \\
\text { sieve + soil } \\
\text { retained }(\mathrm{g})\end{array}$ & $\begin{array}{l}\text { Weight of } \\
\text { soil } \\
\text { retained } \\
(\mathrm{g})\end{array}$ & $\begin{array}{l}\text { \% of soil } \\
\text { retained } \\
(\mathrm{g})\end{array}$ & $\begin{array}{l}\text { Weight of } \\
\text { soil } \\
\text { passing } \\
(\mathrm{g})\end{array}$ & $\begin{array}{l}\text { Cum. \% of } \\
\text { soil } \\
\text { retained } \\
(\%)\end{array}$ & $\begin{array}{l}\% \\
\text { passing }\end{array}$ & $\begin{array}{l}\% \\
\text { finer } \\
(\%)\end{array}$ \\
\hline 3.35 & 498 & 560 & 62.0 & 12.9 & 434 & 12.9 & 90.04 & 87.1 \\
2.36 & 487 & 547 & 60.0 & 12.5 & 374 & 25.4 & 77.59 & 74.6 \\
1.70 & 478 & 547 & 69.0 & 14.3 & 305 & 39.7 & 63.29 & 60.3 \\
1.18 & 458 & 528 & 70.0 & 14.5 & 235 & 54.2 & 48.76 & 45.8 \\
0.850 & 437 & 481 & 44.0 & 9.1 & 191 & 63.3 & 39.63 & 36.7 \\
0.425 & 403 & 477 & 74.0 & 15.4 & 117 & 78.7 & 24.27 & 21.3 \\
0.212 & 382 & 438 & 56.0 & 11.6 & 61 & 90.3 & 12.66 & 9.7 \\
0.150 & 365 & 391 & 26.0 & 5.4 & 35 & 95.7 & 7.26 & 4.3 \\
0.075 & 359 & 378 & 19.0 & 3.9 & 16 & 99.6 & 3.32 & 0.4 \\
0.63 & 358 & 360 & 2.0 & 0.4 & 14 & 100 & 2.91 & 0.00 \\
Pan & 328 & 328 & 0.00 & 0.00 & 0.00 & 0.00 & 0.00 & 0.00 \\
\hline
\end{tabular}

Table 3: Particles size distribution result for Emure sand sample.

\begin{tabular}{|c|c|c|c|c|c|c|c|c|}
\hline $\begin{array}{l}\text { Sieve } \\
\text { size } \\
(\mathrm{mm})\end{array}$ & $\begin{array}{l}\text { Weight of } \\
\text { empty } \\
\text { sieve (g) }\end{array}$ & $\begin{array}{l}\text { Weight of } \\
\text { sieve }+ \text { soil } \\
\text { retained }(\mathrm{g})\end{array}$ & $\begin{array}{l}\text { Weight of } \\
\text { soil } \\
\text { retained } \\
\text { (g) }\end{array}$ & $\begin{array}{l}\text { \% of soil } \\
\text { retained } \\
(\mathrm{g})\end{array}$ & $\begin{array}{l}\text { Weight of } \\
\text { soil } \\
\text { passing } \\
\text { (g) }\end{array}$ & $\begin{array}{l}\text { Cum. \% of } \\
\text { soil } \\
\text { retained } \\
(\%)\end{array}$ & $\begin{array}{l}\% \\
\text { passing }\end{array}$ & $\begin{array}{l}\% \\
\text { finer } \\
(\%)\end{array}$ \\
\hline 3.35 & 498 & 506 & 8.0 & 1.6 & 495 & 1.6 & 98.8 & 98.4 \\
\hline 2.36 & 487 & 498 & 11.0 & 2.2 & 484 & 3.8 & 96.6 & 96.2 \\
\hline 1.70 & 478 & 510 & 32.0 & 6.4 & 452 & 10.2 & 90.2 & 89.8 \\
\hline 1.18 & 458 & 525 & 67.0 & 13.4 & 385 & 23.6 & 76.8 & 76.4 \\
\hline 0.850 & 437 & 492 & 55.0 & 11.0 & 330 & 34.6 & 65.9 & 65.4 \\
\hline 0.425 & 403 & 528 & 125.0 & 25.0 & 205 & 59.6 & 40.9 & 40.4 \\
\hline 0.212 & 382 & 507 & 125.0 & 25.0 & 80 & 84.6 & 15.97 & 15.4 \\
\hline 0.150 & 365 & 413 & 48.0 & 9.6 & 32 & 94.2 & 6.4 & 5.8 \\
\hline 0.075 & 359 & 383 & 24.0 & 4.8 & 6 & 99 & 1.2 & 1.0 \\
\hline 0.63 & 358 & 364 & 6.0 & 1.2 & 2 & 100 & 0.4 & 0.0 \\
\hline Pan & 328 & 328 & 0.00 & 0.00 & 0.00 & 0.00 & 0.00 & 0.00 \\
\hline
\end{tabular}

Source: Author laboratory work, 2019.

Table 4: Compressive strength of sandcrete cube on day 7, 14, 21 and 28.

\begin{tabular}{|c|c|c|}
\hline Days & $\begin{array}{l}\text { Samples (Fine } \\
\text { Aggregate } \\
\text { Location) }\end{array}$ & $\begin{array}{l}\text { Average Compressive } \\
\text { Strength }\left(\mathrm{N} / \mathrm{Mm}^{2}\right)\end{array}$ \\
\hline 7 & Ipele & $4 \mathrm{~N} / \mathrm{mm}^{2}$ \\
\hline 14 & Ipele & $4 \mathrm{~N} / \mathrm{mm}^{2}$ \\
\hline 21 & Ipele & $4.15 \mathrm{~N} / \mathrm{mm}^{2}$ \\
\hline 28 & Ipele & $4.15 \mathrm{~N} / \mathrm{mm}^{2}$ \\
\hline 7 & Shagari & $2.96 \mathrm{~N} / \mathrm{mm}^{2}$ \\
\hline 14 & Shagari & $3.41 \mathrm{~N} / \mathrm{mm}^{2}$ \\
\hline 21 & Shagari & $3.48 \mathrm{~N} / \mathrm{mm}^{2}$ \\
\hline 28 & Shagari & $3.56 \mathrm{~N} / \mathrm{mm}^{2}$ \\
\hline 7 & Emure & $3.85 \mathrm{~N} / \mathrm{mm}^{2}$ \\
\hline 14 & Emure & $4.59 \mathrm{~N} / \mathrm{mm}^{2}$ \\
\hline 21 & Emure & $4.96 \mathrm{~N} / \mathrm{mm}^{2}$ \\
\hline 28 & Emure & $5.48 \mathrm{~N} / \mathrm{mm}^{2}$ \\
\hline
\end{tabular}

Source: Authors laboratory works, 2019.
Table 4 shows the results of average compressive strength of sandcrete cubes on day 7, 14, 21 and 28 for each sample. The table also shows that compressive strength of Ipele sandcrete cube is same at day $7 \& 14$ also same at day $21 \& 28$. Shagari and Emure sandcrete cubes has their lowest compressive strength at day 7 and their highest compressive strength at day 28.

\section{SUMMARY OF FINDINGS}

This research carried out shows that the Emure sand contains more fines particle with $98.4 \%$, follow by Ipele sand $97.6 \%$ and Shagari sand with $87.1 \%$. This research work also show that Emure sand to sandcrete cube improve the compressive strength of sandcrete blocks as shown in Table 4, although Ipele sand sandcrete cube has it highest compressive strength on day 21 and 28 which is $4.15 \mathrm{~N} / \mathrm{mm} 2$. On 
day 28 Shagari sand sandcrete cube has it highest compressive strength with $3.56 \mathrm{~N} / \mathrm{mm} 2$. On day 14 , 21 and 28 Emure sand sandcrete cube has highest compressive strength with $4.59 \mathrm{~N} / \mathrm{mm} 2,4.96 \mathrm{~N} / \mathrm{mm} 2$ and $5.48 \mathrm{~N} / \mathrm{mm} 2$ respectively.

\section{CONCLUSION}

This research work compared the compressive strength of sandcrete blocks produced with fine aggregate (sand) from different source in Owo Local Government Area, Ondo State, Nigeria. From the results gotten it was revealed that the sandcrete cube produced with fine aggregate (sand) from various sources comply with the minimum standard requirement compressive strength value of $2.5 \mathrm{~N} / \mathrm{mm} 2$ for non-load bearing or $3.45 \mathrm{~N} / \mathrm{mm} 2$ for load bearing walls at 28 days of curing. But among the fine aggregate (sand) Emure sand came first with compressive strength of $5.48 \mathrm{~N} / \mathrm{mm} 2$ follow by Ipele sand with $4.15 \mathrm{~N} / \mathrm{mm} 2$ and Shagari sand with compressive strength of $3.56 \mathrm{~N} / \mathrm{mm} 2$.

\section{RECOMMENDATIONS}

Based on the research findings the following are hereby recommended;

1. Emure fine aggregate (sand) has the optimum compressive strength therefore this sand is recommend for production of sandcrete block in Owo Local Government Area.

2. Curing should be properly done, because it was observed from the results that the compressive strength of sandcrete cube increased at each crushing days.

3. I also recommend that workshops and seminars should be organized periodically to enlighten producers of sandcrete blocks on the importance of adhering to standard. This will reduce cracks and defects in wall.

\section{REFERENCES}

[1] British standards (BS-6073): Precast concrete masonry units part 1: Specification for precast concrete masonry units; part II: methods for specifying precast masonry units. British standard institute, London. 1981.

[2] Baiden, B.K and Tuuli, M. 'Impact of quality control practices in sandcrete blocks production.' Journal of Architectural Engineering, Vol. 10, Number 2, 2004, pp 5560.
[3] Aitcin, P-C. \& Mindess, S. Sustainability of concrete (Modern Concrete technology series).CRC Press. London, 2011

[4] Oyekan and Kamiyo. 'A study on the engineering properties of sandcrete blocks produced with rice husk ash blended cement.' Journal of Engineering and Technology Research vol. 03, Number 03, 2011, pp. 88-98.

[5] Oyekan, G.L. "Effect of Granite fines on the compressive strength of sandcrete blocks" Proceedings of conference of construction Technology. Contect- sahah, Malaysia.2001, Pp. 14-17,

[6] NIS 2000. NIS 87: Nigeria Industrial standard: Standard for sandcrete blocks. Standards organization of Nigeria, Lagos, Nigeria. 2004

[7] Anosike, M.N and Oyebade, A.A "Journal of Engineering, Project and Production Management," Vol. 2, 2012 pp 37-46.

[8] R. Barry, The construction of Building. Vol. I. Crosby Lockwood, London, England.

[9] Abdulwahab, R. and Tunde, M.A. "The effects of production methods on the compressive strength of hollow sandcrete blocks," Journal of Materials and Engineering structures, Vol. 3,2016 pp. 197-204.

[10] Odeyemi, S.O. "Effect of Types of sandcrete Blocks on the Internal Microclimate of a Building." Journal of Research Information in Civil Engineering (RICE), Department of Civil Enginering, University of Ilorin, Ilorin, Nigeria. Vol. 9, 2012 pp. 96- 107.

[11] Oyetola and Abdullahi,M. "Properties of some Fine Aggregate in Minna. Nigeria and Environs." Leonardo Journal of Science, Vol. 8, 2006, pp. 1-6.

[12] Ewa, D.E and Ukpata, J.O. "Investigation of the compressive strength of commercial sandcrete blocks in Calabar Nigeria." International Journal of Engineering and Technology, Vol. 3 Number 4, 2013, pp. 477482.

[13] Aiyewalehinmi, E.O and Tanimola, M.O. "Strength properties of commercially produced sandcrete block in Akure. Ondo state." International Journal of Engineering science Invention, Vol. 2, Number 5, 2013, pp 22-33.

[14] Mahmoud, $\mathrm{H}$. et al. 'Compressive strength of Marketed Sandcrete Blocks produced in Yola, Nigeria." Journal of Engineering and Applied sciences, Vol. 2, 2010, pp 74-81. 
[15] Okoli, O.G. et al. 'Assessment of Early compressive strength development of concrete with selected ordinary protland cement". NJCTM. Vol. 9, Number 1, pp.1824, 2008

[16] Chandrasekhar,S. et. al. "Processing, Properties and applications of reactive silica from rice husk- an overview.' Material. Sci., 38 (15), pp. 3159-3168, 2003.

[17] Samson, D. et. al. "Quality assessment of hollow sandcrete blocks.' NJERD Vol. I, Number 03, 2002.pp. 37-46.

[18] Abdullahi, M. "Compressive strength of sandcrete blocks in Bosso and Shiroro area of Minna,Nigeria." A.U.J.T Vol 9 Number 02, 2005, pp. 126-132.

[19] Nunnally, S.W. Construction method and management. Pearson Education Inc. Merril Prentice Hall. 7th edition . ISBN:0-131716885-9.2007

[20] Ogunsanmi, O.E, et. al. "Risk classification model for design and Build projects.' Journal of Engineering, projects and production management (EPPM), Vol I. Number I, 2011, pp. $46-60$

[21] Okafor, F.O and Ewa, D. 'Predicting the compressive strength of Obudu Earth blocks stabilized with cement kiln dust.' Nigerian Journal of Technology. Vol.31, No. 1, 2012. Pp. 149-155.

[22] Raheem, A.A. "Comparism of the Quality of Sandcrete Blocks produced by LAUTECH Block industry with others within Ogbomoso Township." Science Focus, Vol. 03 Number 01, 2006, Pp 103-108.

[23] Boeck, L. et.al."Sandcrete blocks for buildings. A detailed study on mix compositions, strength and their cost." The Nigerian Engineer: Vol. 38, Number 01, 2000, Pp 2433.

[24] Odeyemi, S.O, et.al. "Compressive strength of manual and machine compacted sandcrete hollow blocks produced from brands of Nigerian cement," American Journal of Civil Eng. Vol. 03, 2015, Pp 2-3.

[25] Oyekan, G.I, and Kamiyo, O.M.'Effects of Granites Fines on the structural and Hygrothemal properties of Sandcrete Blocks." Journal of Engineering and Applied Sciences. Vol.03 Number 09, 2008, Pp. 735-741.

[26] Afolayan, J.O, et.al. "Characterisation of the compressive strength sandcrete blocks in Ondo state, Nigeria.' Journal of CER \& P Vol. 5 Number 01, 2008, Pp.15-28. 